\title{
Jaringan Komunikasi tentang Isu Polemik Audisi Perkumpulan Bulutangkis Djarum tahun 2019 di Twitter
}

\author{
Miftakhul Fikri', Andre Rahmanto ${ }^{2}$, Basuki Agus Suparno ${ }^{3}$ \\ ${ }^{1,2}$ Prodi Magister Ilmu Komunikasi, Fakultas Ilmu Sosial dan Politik, \\ Universitas Sebelas Maret Surakarta \\ Jl. Ir. Sutami No. 36 A, Pucangsawit, Kec. Jebres, Kota Surakarta, Jawa Tengah, 57126 Indonesia \\ ${ }^{3}$ Prodi Magister Ilmu Komunikasi, Fakultas Ilmu Sosial dan Ilmu Politik, \\ Universitas Pembangunan Nasional Veteran Yogyakarta \\ Jl. Ring Road Utara No. 104 Ngropoh, Condongcatur, Kec. Depok, Kab. Sleman, Yogyakarta, 55283 Indonesia \\ E-mail: miftahulfikri24@gmail.com ${ }^{1 *}$; andreyuda@gmail.com²; basuki.agus@gmail.com³ \\ *Corresponding author
}

\begin{abstract}
The problem of the Djarum 2019 Badminton Association (PB) audition polemic issue led to many interactions that attracted the attention of the Indonesian people. The interaction pattern on Twitter can be identified with the communication network. This study aims to analyze a centralized communication network about PB polemic issues on Twitter by the@PBDjarum and@lenteraanak_accounts. The research method used is descriptive qualitative, with data collection techniques using data mining on Twitter with the help of Gephi software. Data analysis uses centralized communication network analysis which is divided into actor, group, and network structure level analysis. The results of the study were a centralized communication networkby the@PBDjarum account which resulted in interactions with 604 accounts, 13 intermediary groups, and a strong network structure. Meanwhile, the centralized communication network by the@ lenteraanak_account resulted in interactions with 253 accounts, 16 intermediary groups, and a strong network structure. This study concludes that the centralized communication network by the @PBDjarum and @lenteraanak_accounts on Twitter about PB Djarum's audition polemic has caused many interactions with other accounts so that the development of the problem quickly spreads to various Indonesians. The substance of this research provides a new method of analysis of communication networks on an issue that can distinguish the characteristics of a centralized communication network on each account on Twitter. Keywords: Communication Network; New Media; Social Media; Twitter; PB Djarum
\end{abstract}

\begin{abstract}
Abstrak
Permasalahan isu polemik audisi Perkumpulan Bulutangkis (PB) Djarum 2019 memunculkan banyak interaksi sehingga menarik perhatian masyarakat Indonesia. Pola interaksi di Twitter tersebut dapat diketahui dengan jaringan komunikasi. Penelitian ini bertujuan untuk menganalisis jaringan komunikasi terpusat tentang masalah polemik PB di Twitter oleh akun@PBDjarum dan@lenteraanak. Metode penelitian yang digunakan yaitu kualitatif deskriptif, dengan teknik pengumpulan data menggunakan penambangan data di Twitter dengan bantuan perangkat lunak Gephi. Analisis data menggunakan analisis jaringan komunikasi terpusat yang terbagi pada analisis tingkat aktor, kelompok, dan struktur jaringan. Hasil penelitian berupa jaringan komunikasi terpusat oleh akun@PBDjarum yang menghasilkan interaksi dengan 604 akun, 13 kelompok perantara, dan struktur jaringan yang kuat. Sementara jaringan komunikasi terpusat oleh akun @ lenteraanak_menghasilkan interaksi dengan 253 akun, 16 kelompok perantara, dan struktur jaringan yang kuat. Penelitian ini menyimpulkan bahwa jaringan komunikasi terpusat oleh akun@PBDjarum dan@ lenteraanak_di Twitter tentang polemik audisi PB Djarum telah menyebabkan banyak interaksi dengan akun lain sehingga perkembangan masalah tersebut dengan cepat menyebar ke berbagai masyarakat Indonesia. Substansi penelitian ini memberikan metode baru berupa analisis jaringan komunikasi tentang sebuah isu yang bisa membedakan karakteristik jaringan komunikasi terpusat pada setiap akun di Twitter. Kata Kunci: Jaringan Komunikasi; Media Baru; Media Sosial; Twitter; PB Djarum
\end{abstract}

\section{Pendahuluan}

Isu polemik audisi PB Djarum 2019 banyak memunculkan berbagai interaksi masyarakat Indonesia. Permasalahan tersebut diawali dengan munculnya berbagai komentar atau tanggapan oleh pengguna Twitter. Sebagian pengguna Twitter yang mendukung audisi PB Djarum dan ada pula pengguna yang menentang 
audisi PB Djarum. Pro dan kontra tanggapan pada audisi PB Djarum 2019 disebabkan adanya beberapa pengguna Twitter yang menyebarkan informasi mengenai laporan dugaan eksploitasi anak pada audisi PB Djarum.

Pengguna Twitter yang mendukung audisi PB Djarum 2019 beranggapan PB Djarum memberikan bantuan dengan tepat di bidang olahraga badminton di Indonesia dan berasumsi PB Djarum dianggap sudah diperkirakan baik kehadirannya dengan adanya audisi pencarian bakat pemain badminton Indonesia di tingkat anak-anak. Pengguna Twitter yang menentang PB Djarum melihat program audisi PB Djarum 2019 hanya berupaya melakukan ajang promosi brand rokok Djarum secara terselubung kepada anakanak yaitu mengeksploitasi mereka pada audisi.

Pada 8 Agustus 2019, salah satu pengguna Twitter yang menentang audisi PB Djarum 2019 adalah Yayasan Lentera Anak. Melalui akun@lenteraanak_yayasan itu membuat kicauan-kicauan mengenai laporan dugaan ekploitasi anak pada audisi PB Djarum 2019. Tweet-tweet tersebut juga disertakan beberapa tagar utama yaitu \#TangkisEksploitasiAnak dan \#JanganMauDitipu sebagai penanda topik di Twitter. Tweet tersebut memunculkan banyak komentar oleh pengguna Twitter lainnya. Selanjutnya dari tweet tersebut Yayasan Lentera Anak mendesak KPAI sebagai lembaga negara pemerintah Indonesia untuk menindaklanjuti adanya dugaan eksploitasi anak pada audisi PB Djarum 2019.

Pada 7 September 2019 percakapan isu polemik audisi PB Djarum meningkat interaksinya yaitu ketika PB Djarum melalui akun Twitter-nya (@PBDjarum) menyatakan "Ini tahun terakhir audisi, DJARUM PAMIT!!!". Tweet tersebut juga disertakan tagar utama yaitu \#AUDBB2019, \#PerjalananEmasBulutangkis dan\#PBDjarum sebagai penandatopik. Dari tweet itu banyak pengguna Twitter yang berkomentar atas berakhirnya audisi PB Djarum di tahun 2019. Mereka juga berkomentar menyalahkan
Komisi Perlindungan Anak Indonesia (KPAI) atas informasi berakhirnya audisi PB Djarum 2019. KPAI dituduh hanya mencari masalah pada PB Djarum. Dari banyaknya kicauan di Twitter, terlihat masalah selanjutnya yaitu mengenai banyak tweet yang dibuat oleh pengguna Twitter memunculkan banyak interaksi mengenai isu polemik audisi PB Djarum 2019.

Terdapat fenomena menarik mengenai penggunaan Twitteryang mengalami peningkatan dibandingkan tahun-tahun sebelumnya di Indonesia. Hal itu terbukti pada riset yang dilakukan oleh Hootsuite dan We Are Social tentang data internet, media sosial, mobile, dan perilaku konsumen di 2019. Riset menunjukkan temuan media sosial Twitter telah digunakan oleh $65 \%$ laki-laki dan 35\% perempuan di Indonesia. Selanjutnya $3 \%$ penduduk Indonesia yang berumur 13 tahun ke atas telah menggunakan Twitter (We Are Social \& Hootsuite, 2019).

Cara untuk mengetahui pengguna Twitter yang mendukung serta menentang audisi PB Djarum 2019 yaitu dengan mengenal siapa aktornya dan bagaimana interaksi yang terbangun. Hal itu dapat diketahui dengan melakukan penelitian jaringan komunikasi. Jaringan komunikasi mengenalkan beberapa konsep penelitian yaitu konsep aktor (node) dan konsep relasi antaraktor (edge). Penelitian jaringan komunikasi menjadi suatu analisis siapa saja aktornya dan bagaimana relasi antaraktor di dalam jaringan. Penelitian jaringan komunikasi digunakan untuk memeriksa interaksi antaraktor atau interaksi antar pengguna Twitter.

Pada penelitian ini penggunaan analisis jaringan komunikasi dimaksudkan untuk membahas siapa saja pengguna Twitter yang membicarakan isu polemik eksploitasi anak pada audisi PB Djarum 2019. Selain itu, penggunaan analisis jaringan komunikasi juga ditujukkan untuk mengetahui bagaimana relasi antarpengguna Twitter yang melakukan banyak interaksi tentang audisi PB Djarum 2019. 
Riset terkait dengan program PB Djarum saat ini baru sebatas pemberitaan program, tanggung jawab sosial perusahaan, atau implementasi dari programnya saja. Riset sebelumnya belum membahas jaringan komunikasi yang terbentuk antar pengguna Twitter yang mendukung dan pengguna Twitter yang menentang audisi PB Djarum-2019. Berdasarkan alasan tersebut, maka peneliti mengusulkan riset studi analisis jaringan komunikasi di Twitter tentang isu polemik eksploitasi anak pada audisi PB Djarum 2019. Ada pula tujuan penelitian ini untuk mengetahui jaringan komunikasi isu polemik audisi PB Djarum 2019 di Twitter.

Penelitian jaringan komunikasi sebelumnya telah dilakukan sebatas pada keluarga, komunitas, kelompok ataupun organisasi. Ada riset yang membahas jaringan komunikasi keluarga peternak sapi dalam menentukan konsumsi anggota keluarganya (Wardyaningrum, 2010). Hasil riset menunjukkan terdapat aktor yaitu ibu yang menjadi penentuan konsumsi di setiap keluarga. Selanjutnya ada beberapa faktor yang memengaruhi penentuan konsumsi seperti waktu dan lingkungan sosial keluarga.

Terdapat riset yang berusaha mengetahui jaringan komunikasi komunitas pengemis untuk bertahan hidup mengembangkan inovasi di Solo (Jk, 2017). Hasil riset menjelaskan ada 33 pengemis sebagai aktor dalam jaringan komunikasi pengemis di kota solo. Selain itu, dari 33 pengemis terdapat 7 aktor yang menjadi pemuka pendapat dalam jaringan komunikasi komunitas pengemis di Solo.

Penelitian sebelumnya tentang jaringan komunikasi di media sosial Twitter, Instagram dan Facebook telah dilakukan riset pertama yaitu mengidentifikasi aktor utama di Twitter untuk mengetahui isu keberlanjutan organisasi, hubungan masyarakat, dan tanggung jawab sosial perusahaan (Lipschultz, 2017). Hasil riset menunjukkan akun Twitter yang bisa mempengaruhi keberlanjutan isu pada keberlanjutan organisasi, hubungan masyarakat dan tanggung jawab sosial perusahaan di Twitter akun@nsrgreanaissance. Selain itu, untuk mempengaruhi isu keberlanjutan organisasi, hubungan masyarakat dan tanggung jawab sosial perusahaan di Twitter dalam jaringan komunikasi ialah \#sustainability. Data jaringan komunikasi keseluruhan pada 30 akun Twitter.

Penelitian selanjutnya bertujuan untuk menemukan aktor yang paling berperan dalam jaringankomunikasiPT.NetMediatama Indonesia di Twitter (Ramadhani, Alamsyah, \& Wicaksono, 2018). Hasil penelitian menunjukkan didapatkan aktor utama dalam jaringan komunikasi NET di Twitter ialah akun@chuuattac. Akun tersebut dapat digunakan sebagai salah satu alternatif strategi pemasaran dalam mengkampanyekan produk dan menyebarkan informasi NET dengan lebih cepat dan tepat sasaran di Twitter.

Riset yang berusaha meneliti dengan cara mengidentifikasi aktivitas penyebaran tagar \#RatnaMilikSiapa menggunakan metode jaringan komunikasi di Twitter (Tomasoa, Iriani, \& Sembiring, 2019). Penelitian itu menghasilkan aktor yang memiliki popularitas dengan derajat sentralitas tertinggi yaitu @04nak,@AkunT,dan@CH_choti.Akun-akun Twitter tersebut diketahui pula menyebarkan informasi berupa berita-berita dalam tweettweet-nya sebagai reaksi pada \#RatnaMilikSiapa di Twitter. Selain itu, akun@04nak,@AkunT, dan@CH_choti juga melakukan pertukaran informasi setelah dianalisis menggunakan analisis sentralitas keperantaraan aktor-aktor. Akhirnya relasi dalam jaringan komunikasi pada \#RatnaMilikSiapa ditentukanoleh ketiga akunitu.

Penelitian jaringan komunikasi di media sosial tidak hanya terbatas pada Twitter saja. Penelitian sebelumnya yang membahas karakteristik pola jaringan komunikasi pada akun (a)exploremalang di Instagram (Nandiwardhana, Pratama, \& Tamitiadini, 2019). Hasil penelitian menjelaskan terdapat aktor yang memiliki popularitas dalam jaringan komunikasi pada akun @exploremalang di Instagram adalah akun@ nuansafira. Selanjutnyaklik-klik kelompok dalam 
jaringan komunikasi yang saling melakukan hubungan kuat antar akun-akun instagram. Hasil riset ialah struktur jaringan komunikasi yang diukur kepadatan jaringannya lemah. Penelitian jaringan komunikasi di media sosial Facebook juga telah dilakukan.-Penelitian yang dilakukan oleh Sugiarta dkk bertujuan untuk mengetahui aktor-aktor dalam jaringan komunikasi group facebook pada Lembaga Survei Politik Indonesia (Sugiarta, Syamsuar, \& Negara, 2018). Hasil dari penelitian adalah akun Facebook Sri Fajar menjadi aktor yang memiliki popularitas paling tinggi dalam jaringan komunikasi group facebook pada Lembaga Survei Politik Indonesia. Akhirnya akun tersebut menjadi sentral atas penyebaran informasi politik di group facebook Lembaga Survei Politik Indonesia.

Penelitian sebelumnya yang telah dikutip oleh peneliti masih sebatas pada pembahasan mengenai aktor-aktor atau akun-akun yang populer dalam jaringan komunikasi di media sosial. Peneliti melihat perlu ada kebaruan penelitian jaringan komunikasi di media sosial. Peneliti mengusulkan kebaruan penelitian pada pentingnya sebuah isu di Twitter yang menjadi perbincangan banyak orang sehingga dapat menarik perhatian yang tinggi dari berbagai lapisan masyarakat Indonesia. Perbincangan isu di Twitter dapat diketahui dari jumlah akun yang melakukan interaksi serta relasinya melalui penelitian jaringan komunikasi secara terpusat. Jaringan komunikasi terpusat di Twitter mengidentifikasiakun terpusatyangmenyebarkan informasi sehingga interaksi yang begitu cepat dan luas dapat diketahui. Pertimbangan kebaruan penelitian jaringan komunikasi terpusat di Twitter untuk mengetahui perkembangan sebuah isu tentang polemik audisi PB Djarum 2019 perlu dilakukan pada penelitian ini.

Kemunculan teori jaringan komunikasi diawali dengan adanya penjelasan mengenai analisis jaringan sosial. Analisis jaringan sosial didefinisikan terdapat konsep-konsep kunci yang saling berhubungan sehingga analisis jaringan sosial didiskusikan bagaimana perbedaan tingkat analisisnya (Wasserman \& Faust, 1994). Konsep pertama jaringan sosial adalah adanya entitas sosial yang saling memiliki keterhubungan. Dalam analisis jaringan sosial terdapat pemahaman bahwa pada sebuah jaringan sosial memperhatikan adanya saling keterhubungan oleh sejumlah entitas sosial sehingga entitas sosial berimplikasi pada keterhubungannya. Entitas sosial bisa juga disebut sebagai aktor (actor). Aktor bisa berupa individu-individu, ataupun beberapa unit sosial lainnya. Aktor dapat pula dicontohkan seperti orang-orang dalam sebuah kelompok, departemen-departemen di dalam perusahaan, agen-agen pemerintahan dalam suatu kota atau negara-negara dalam sebuah sistem dunia. Penggunaan istilah aktor bukan memberi pengertian aktor yang memiliki aksi, melainkan penerapan jaringan sosial yang memfokuskan adanya usaha mengkoleksi aktor-aktor pada satu kesamaan jenis.

Konsep selanjutnya dalam jaringan sosial ialah adanya ikatan relasional (relational tie). Sebuah ikatan relasional mengikat aktor satu dengan aktor lainnya sehingga memiliki hubungan. Adanya ikatan relasional menetapkan keterhubungan antar aktor di jaringan sosial. Ada beberapa contoh ikatan relasional dalam di analisis jaringan sosial seperti ekspresi pertemanan antar individu, transaksi barang, kegiatan sosial, interaksi berbicara bersama, perubahan status sosial dan ikatan lainnya.

Untuk mengetahui perbedaan tingkat dalam analisis jaringan sosial maka akan dijelaskan konsep selanjutnya yaitu dyad. Dyad termasuk konsep lanjutan setelah adanya konsep ikatan relasional. Dyad dijelaskan sebagai keterhubungan yang membentuk sebuah ikatan diantara dua aktor. Satu dyad bisa juga disebut sebagai satu unit analisis. Pembentukan satu dyad pada satu pasangan aktor memungkinkan adanya ikatan diantara aktor-aktor tersebut. Konsep dyad menjadi tingkatan dasar dalam melakukan analisis jaringan sosial. Analisis 
itu dikenal sebagai analisis dyadic. Selain itu, terdapat konsep lanjutan setelah dyad yaitu triad. Triad menunjuk pada keterhubungan yang terjadi oleh banyaknya subjek aktor lebih dari dua aktor yang memungkinkan pada analisis jaringan sosial. Triad bisa dikatakan pula sebagai satu bagian pada tiga aktor yang memungkinkan ikatan diantara aktor-aktor tersebut. Analisis pada konsep triad disebut analisis triadic.

Setelah diketahui perbedaan tingkatan analisis jaringan sosial pada konsep dyad dan triadic maka selanjutnya dijelaskan konsep yaitu sub kelompok (subgroup). Subgroup merupakan konsep yang menggambarkan adanya pasanganpasangan antar (dyad atau triad) yang saling berhubungan pada sebuah ikatan, baik itu dyad dengan dyad ataupun dyad dengan triad ataupun sebaliknya. Subgroup menggunakan kriteria khusus sehingga menjadi penting dalam analisis jaringan sosial. Sebenarnya analisis jaringan sosial tidak hanya terbatas pada konsep dyadic, triadic ataupun subgroup namun lebih besar lagi untuk mengetahui kekuatan analisis jaringan sosial maka perlu diketahui pula selanjutnya mengenai keterhubungan di sejumlah sistem antara aktor-aktor. Setelah diketahui konsep subgroup maka konsep lanjutan dalam analisis jaringan sosial yaitu kelompok (group). Group merupakan kumpulan semua aktor dalam suatu ikatan yang diukur di jaringan sosial. Konsep group menentukan keseluruhan kumpulan aktor-aktor yang hendak diukur sehingga disebut sebagai satu set aktor (actor set). Oleh karena itu, jaringan sosial bisa terdiri dari banyak kelompok aktor-aktor, akan tetapi hanya terdapat satu set aktor saja.

Konsep terakhir dalam analisis jaringan sosial adalah relasi-relasi (relations). Relations berisi kumpulan sejumlah ikatan relasional yang spesifik serta berisi sejumlah aktor dalam sebuah kelompok seperti satu set pertemanan di sejumlah pasangan anak-anak dalam sebuah kelas ataupun satu set ikatan diplomasi negara-negara di dunia internasional. Contoh tersebut dapat definisikan juga sebagai sebuah relasi (relation). Catatan yang perlu diketahui bahwa relasi mengacu pada kumpulanjenisikatanyang diukurdalampasangan aktor dari satu set aktor yang lebih spesifik.

Jaringan komunikasi menjelaskan adanya keterhubungan yang bisa diaplikasikan pada berbagai macam level analisis dari kelompok kecil sampai sistem global di dunia (Kadushin, 2012). Jaringan komunikasi menjelaskan beberapa konsep seperti jaringan, keterhubungan, homofili, dyad, dan kebersamaan serta keseimbangan. Jaringan komunikasi selanjutnya menjadi suatu jalan atau metode untuk memudahkan peneliti melakukan penelitian jaringan komunikasi. Analisis jaringan komunikasi ialah metode yang dilakukan peneliti untuk melihat struktur komunikasi, popularitas aktor-aktor dan jumlah kelompok dalam jaringan komunikasi (Eriyanto, 2014). Terdapat beberapa konsep analisis jaringan komunikasi seperti node dan edge, tipe relasi jaringan komunikasi, struktur jaringan komunikasi dan aliran jaringan komunikasi.

Konsep awal analisis jaringan komunikasi ialah aktor (node) dan ikatan (edge). Aktoraktor yang mempunyai ikatan ialah aktoraktor yang digambarkan memiliki gambar garis antar aktor, apabila para aktor tidak memiliki gambar garis maka aktor tersebut dapat dikatakan tidak memiliki ikatan.

Setelah mengetahui konsep awal analisis jaringan komunikasi maka konsep lanjutannya yaitu tipe relasi jaringan komunikasi. Ada beberapa jenis mengenai konsep tipe relasi seperti one mode dan two mode, directed dan undirected, simetris dan asimetris serta valued dan unvalued. Tipe relasi one mode ialah jaringan komunikasi yang didalamnya terdapat aktor yang sama seperti contohnya antar individu, antar lembaga dan sebagainya. Tipe relasi two mode adalah jaringan komunikasi yang terdiri dari aktor-aktor yang berbeda misalnya ada aktor individu, lembaga dan sebagainya. Tipe relasi directed ialah jaringan komunikasi yang terdiri dari aktor pengirim dan aktor penerima yang 
mempunyai arah atau tanda panah. Tipe relasi undirected adalah jaringan komunikasi yang tidak ada aktor pengirim dan aktor penerima serta tidak mempunyai arah. Tipe relasi simetris ialah jaringan komunikasi yang terdapat aktor-aktor yang memiliki hubungan satu arah saja. Tipe relasi asimetris ialah jaringan komunikasi yang aktor-aktornya saling berhubungan dua arah atau hubungan timbal balik. Terakhir tipe relasi valued adalah jaringan komunikasi terdapat aktor-aktor yang memiliki intensitas arah hubungannya sedangkan jenis tipe relasi unvalued ialah jaringan komunikasi aktor-aktor tidak memiliki intensitas arah hubungannya sama sekali.

Konsep selanjutnya setelah tipe relasi jaringan komunikasi yaitu konsep struktur jaringan komunikasi. Struktur jaringan komunikasi sebagai salah satu konsep analisis jaringan komunikasi memiliki elemen-elemen yang saling berhubungan seperti komponen, klik, bridges, hubs, cutpoint dan pemencil. Komponen ialah aktor-aktor pada suatu kelompok memiliki minimal satu ikatan setiap aktornya dalam jaringan komunikasi. Klik adalah aktor-aktor yang semuanya memiliki ikatan antar aktor pada suatu kelompok dalam jaringan komunikasi. Bridges ialah jembatan atau ikatan-ikatan yang menghubungkan beberapa kelompok aktor-aktor dalam jaringan komunikasi. Hubs merupakan aktor-aktor pada suatu kelompok yang mempunyai koneksi paling banyak dengan aktor-aktor lain pada kelompok lain dalam jaringan komunikasi. Cutpoints adalah aktor-aktor pemersatu kelompokkelompok dalam jaringan komunikasi. Terakhir pemencil ialah aktor-aktor tidak mempunyai sama sekali ikatan dalam jaringan komunikasi.

Konsep selanjutnya ialah aliran jaringan komunikasi. Terdapat tiga bentuk aliran jaringan komunikasi seperti path, trail dan walk. Path ialah jalur yang menghubungkan satu aktor dengan aktor lainnya dalam jaringan komunikasi dengan tidak ada pengulangan melewati aktor yang sama. Trail merupakan jejak yang bisa dilalui oleh aktor agar bisa terhubung dengan aktor lain dengan tidak ada pengulangan melewati ikatan yang sama. Walk ialah jalan yang bisa dilewati tanpa ada batasan oleh semua aktor dalam jaringan komunikasi.

Media baru menjadi salah satu konsep pendukung setelah diketahui teori analisis jaringan komunikasi pada penelitian ini. Konsep media baru (new media) dapat dipelajari dengan melihat penjelasan perbedaan era media pertama (the first media ages) dan era media kedua (second media ages) (Holmes, 2005). Era media pertama disebut juga sebagai era media penyiaran. Ciri-ciri era media pertama adalah produksi yang dilakukan oleh media secara terpusat atau dari satu orang ke banyak orang, media hanya melakukan komunikasi satu arah, sebagian besar media cenderung di kontrol oleh negara, media mereproduksi stratifikasi sosial dan ketidaksetaraan sosial, media mengkotak-kotakkan audiens massal, dan media sebagai pembentukan kesadaran sosial. Sedangkan era media kedua disebut juga sebagai era media jaringan atau era media interaktif. Era media kedua memilki ciri-ciri media terdesentralisasi dari banyak media ke banyak media atau banyak media ke sedikit media, media melakukan komunikasi dua arah, media di luar kontrol negara, media sebagai upaya demokratis atau memfasilitasi warga negara, media mempromosikan kesadaran individu dan media berorientasi pada individu.

Media baru adalah ritual yang memiliki makna tersendiri (Carey, 2008). Setiap media baru memiliki potensi ritual dan integrasi akan tetapi memenuhi fungsi ini dengan cara yang berbeda. Penggunaan media baru oleh seseorang bisa dikatakan sebagai ritual bersama sehingga seseorang merasa bagian dari sesuatu yang lebih besar di media. Media baru diritualkan karena media menjadi kebiasaan dan memiliki nilai-nilai yang lebih besar dari penggunaan media itu sendiri. 
Setelah mengetahui konsep media baru maka perlu diketahui pula konsep media sosial (social media). Media sosial dapat diklasifikasikan pada berbagai bentuk seperti projek kolaborasi, blog, komunitas berbagi konten, situs jejaring sosial, dunia permainan virtual, dan dunia sosial virtual (Kaplan \& Haenlein, 2010). Media sosial menjadi klasifikasi projek kolaborasi dengan maksud adanya kemungkinan pembuatan konten secara bersama-sama yang menjadi stimulus pengguna di internet. Contohnya Wikipedia yang memungkinkan pengguna menambah, menghapus dan mengubah konten teks ataupun visualnya. Selanjutnya media sosial diklasifikasikan seperti blog karena blog menimbulkan sebuah interaksi. Blog memang dikelola sendiri oleh pengguna saja akan tetapi blog memberikan kemungkinan interaksi dengan pengguna lain dengan adanya kolom komentar yang bisa digunakan oleh pengguna lain. Media sosial juga diklasifikasikan layaknya komunitas yang berbagi konten berbagai media seperti teks, video, file presentasi dan sebagainya. Banyak pengguna di internet yang bisa berbagi video seperti contohnya di Youtube. Kemudian media sosial diklasifikasikan menjadi situs jejaring sosial dikarenakan pengguna media sosial saling terhubung satu dengan yang lainnya. Pengguna media sosial yang saling terhubung bisa melihat informasi profil antar penggunanya serta berkirim pesan di situs jejaring sosial tersebut. Media sosial juga dapat diklasifikasikan menjadi dunia permainan virtual dimana seorang pengguna dapat direkayasa profil pribadinya menjadi gambar tiga dimensi seperti manusia di dunia nyata. Dunia permainan virtual juga memungkinkan interaksi antar pengguna melalui gambar tiga dimensi yang berbicara layaknya manusia. Terakhir klasifikasi media sosial sebagai dunia virtual sosial, bisa diartikan adanya kehidupan manusia yang kedua di dunia lain diantara pengguna media sosial. Konsep dunia virtual sosial sama seperti dunia permainan virtual akan tetapi dunia virtual sosial tidak ada aturan yang membatasi interaksi antar pengguna media sosial sehingga memungkinkan adanya interaksi melihat secara langsung tatap muka antar pengguna.

Media sosial dapat dikonseptualisasikan menjadi beberapa konsep seperti media berbasis internet, media tak stabil dan selalu berkembang, media interaktifitas, media penghasil nilai guna dan media sebagai komunikasi antar pribadi (Carr \& Hayes, 2015), Media sosial menjadi konsep media berbasis internet karena media sosial menjadi alat yang digunakan pengguna untuk beroperasi melalui internet. Media sosial sebagai media berbasis internet juga dianggap media yang bisa menjangkau lebih luas lagi. Konsep media sosial tidak stabil dan terus berkembang dimana pada saat pengguna media sosial berpartisipasi serta berkomitmen untuk menggunakan media sepenuhnya ataupun secara tidak sepenuhnya. Media sosial dikonseptualisasikan sebagai media interaktivitas karena media sosial sebagai syarat berinteraksi antar pengguna dimana pengguna dapat membedakan interaksi di media sosial. Media sosial menjadi konsep media yang bernilai bagi penggunanya. Nilai yang didapat pengguna media sosial bisa berupa keuntungan ataupun kenyamanan saat menggunakan media sosial. Terakhir, konsep media sosial sebagai media komunikasi massa antar pribadi dimana media sosial memungkinkan penggunanya menyiarkan pesan ke banyak pengguna lain. Tidak hanya menyiarkan pesan saja, media sosial juga memungkinkan penerima pesan dari banyak pengguna lain untuk membalas komentarnya, baik secara pribadi ataupun banyak pengguna.

Konsep terakhir pada penelitian ini yaitu Twitter. Twitter didirikan oleh Jack Dorsey pada 21 Maret 2006 di Amerika Serikat namun baru diluncurkan pada bulan Juli 2006 oleh perusahaan Twitter Inc. yang bermarkas di San fransisco, California, Amerika Serikat. Pada Februari 2019, Twitter tercatat telah memiliki 321 juta pengguna aktif. Twitter merupakan layanan jejaring sosial dan microblogging yang memungkinkan penggunanya untuk 
mengirim dan membaca pesan berbasis teks (Reilly \& Milstein, 2009). Selain itu, Twitter juga dapat didefinisikan sebagai objek digital, sarana eksistensi diri, alat demokrasi, aspirasi masyarakat, kesamaan pendapat dan kebaruan informasi (Murthy, 2013). Selanjutnya Twitter juga telah terbukti digunakan oleh pengguna untuk berkampanye calon presiden melalui tweet-tweetnya sehingga muncul wacana-wacana politik (Firmansyah, 2018).

\section{Metode Penelitian}

Jenis penelitian adalah kualitatif deskriptif. Penelitian deskriptif merupakan penelitian yang menggambarkan secara detail realitas sosial mengenai aktor serta struktur dalam sebuah jaringan (Eriyanto, 2014). Penelitian ini hanya meneliti batasan akun-akun Twitter yang memfokuskan pada batasan interaksi tentang isu polemik audisi PB Djarum 2019 dari bulan Juli 2019 sampai bulan November 2019 dengan batasan tagar \#TangkisEksploitasiAnak \#JanganMauDitipu, \#AUDBB2019 dan \#PerjalananEmasBulutangkis. Data penelitian berupa struktural aktor dari setiap akun Twitter, baik yang pro dan kontra tentang isu polemik audisi PB Djarum 2019. Selain itu, terdapat one-mode network pada data penelitian ini yaitu satu set data jaringan dari akun-akun Twitter yang pro atau satu set data jaringan dari akun-akun Twitter yang kontra tentang isu polemik audisi PB Djarum 2019.

Pengambilan data penelitian menggunakan penambangan data (data mining) di Twitter. Penambangan data di Twitter bisa dilakukan karena pada dasarnya setiap akun Twitter mempunyai grafik jaringan yaitu mengikuti dan diikuti oleh akun-akun di Twitter (Russell \& Klassen, 2019). Pengambilan data di Twitter dilakukan dengan membuat coding python dengan bantuan beberapa instalasi library seperti tweepy, twiter scraper, datetime, csv dan lainnya pada software Pycharm. Coding python yang telah dibuat menggunakan software Pycharm maka data coding python dipindahkan ke software Spyder untuk verifikasi. Selanjutnya, coding python dijalankan di software Spyder yang kemudian secara otomatis menghasilkan data dalam bentuk format data . csv. Hasil data format .csv dimasukkan pada untuk diolah. Software Gephi memvisualisasikan hasil data format .csv menjadi hasil data jaringan. Gephi ialah software yang dapat menampilkan wawasan melalui gambar-gambar dengan cepat serta dengan bersamaan memberikan kemampuan untuk lebih mengeksplorasi jaringan (Cherven, 2013).

Teknik analisis data pada penelitian menggunakan analisis jaringan komunikasi terpusat (ego-centered communication network). Analisis jaringan komunikasi terpusat dibagi pada analisis tingkat aktor-aktor, kelompok dan struktur jaringan. Analisis tingkat aktor atau analisis akun-akun Twitter dalam jaringan komunikasi terpusat dengan cara menganalisis posisional aktor baik pada aktor yang sama (ego) ataupun aktor yang berbeda (alter) dalam satu set data jaringan. Selanjutnya analisis dilakukan dengan cara menganalisis aktor pada ketertutupan jaringan (network closure), celah lubang struktur jaringan oleh aktoraktor (structural holes) dan kekuatan ikatan antar aktor-aktor (tie strength). Ketertutupan jaringan adalah menganalisis tinggi rendahnya keterikatan atau kohesivitas posisi aktor-aktor baik pada ego maupun alter dalam jaringan terpusat (Coleman, 1988). Celah lubang struktur jaringan oleh para aktor ialah menganalisis adanya ruang kosong yang dimana posisi aktoraktor alter menjadi ketergatungan pada aktoraktor ego dalam jaringan terpusat (Lazega \& Burt, 1995). Kekuatan ikatan antar aktor-aktor (tie strength) ialah menganalisis kuat lemahnya ikatan aktor-aktor ego dengan aktor-aktor alter dalam jaringan terpusat (Granovetter, 1973). 
Analisis tingkat kelompok dalam jaringan komunikasi terpusat dengan cara menganalisis bagaimana pola relasi aktor-aktor dalam satu set data jaringan. Analisisnya bisa disebut analisis perantara (brokerage) dalam kelompok. Analisis perantara dalam kelompok dapat dilakukan dengan cara melihat bagaimana posisi ego diantara aktor-aktor lain sehingga menjadi kontrol ego atas aktor-aktor lain dalam kelompok (Fernandez \& Gould, 1994).

Analisis tingkat struktur jaringan komunikasi terpusat dengan cara menganalisis struktur jaringan yang hanya melibatkan ego dan alter saja. Struktur jaringan bisa diketahui analisisnya dari seberapa besar ukuran nilai diameter jaringan dan nilai kepadatan jaringan (Cherven, 2015).

\section{Hasil Penelitian dan Pembahasan}

Pro dan kontra tentang isu polemik audisi PB Djarum tahun 2019 dapat diketahui berdasarkan hasil dan pembahasan jaringan komunikasi terpusat pada sebuah akun Twitter. Pada pembahasan jaringan komunikasi terpusat untuk pro audisi PB Djarum tahun 2019, peneliti memilih akun@PBDjarum sebagai akun terpusat. Akun tersebut dipilih karena informasi awal mengenai audisi PB Djarum 2019 berasal dari tweet di akun@PBDjarum. Peneliti memilih akun@lenteraanak_sebagai akun jaringan komunikasi terpusat untuk kontra audisi PB Djarum 2019. Akun@lenteraanak_dipilih oleh peneliti karena akun itu mengawali tweet-tweet berisi informasi laporan dugaan eksploitasi anak pada audisi PB Djarum tahun 2019. Pada gambar 1 menunjukkan adanya jaringan komunikasi terpusat pada akun@ @ PBDjarum. Terdapat 605 akun dengan 604 interaksi. Akun-akun twitter tersebut digambarkan dengan titik-titik berwarna biru muda sedangkan gambar interaksi digambarkan dengan garis-garis berwarna merah.

Analisis tingkat akun-akun dalam jaringan komunikasi terpusat di @PBDjarum dapat diketahui dengan menganalisis ketertutupan jaringan komunikasi, celah struktur jaringan komunikasi dan ikatan antar akun-akun. Sebelum melakukan analisis, akun@PBDjarum sebagai ego dan akun-akun lain sebagai alter. Analisis

Gambar 1 Jaringan komunikasi terpusat akun@PBDjarum

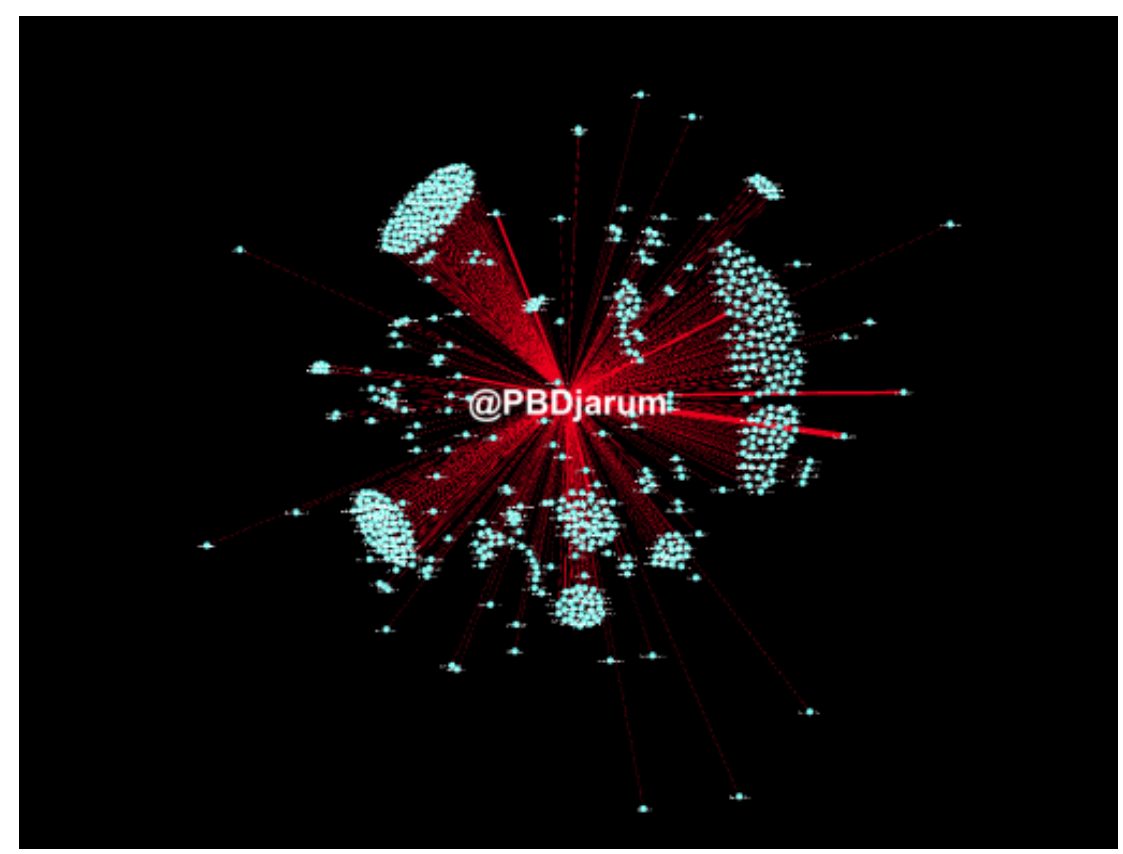

Sumber: Data diolah dari software Gephi (2019) 
ketertutupan jaringan komunikasi dilakukan untuk mengetahui tinggi rendahnya keterikatan diantara akun-akun sebagai alter dalam jaringan komunikasi. Setelah peneliti melakukan analisis ketertutupan jaringan komunikasi maka hasilnya nilai indeks integrasi jaringan komunikasi atau nilai ketertutupan jaringan komunikasi pada jaringan komunikasi terpusat akun@PBDjarum sebesar 0,005. Nilai tersebut menandakan sangat rendahnya keterikatan antar akun sebagai alter dalam jaringan komunikasi. Selain itu, penjelasan sangat rendahnya keterikatan akun-akun sebagai alter dikarenakan mereka tidak saling mengenal satu dengan yang lainnya. Selanjutnya, analisis celah struktur jaringan komunikasi bertujuan untuk mengetahui ruang kosong dalam jaringan komunikasi yang dimana akun@PBDjarum sebagai ego menjadi suatu ketergantungan dari akun-akun lain sebagai alter. Setelah melakukan analisis celah struktur jaringan komunikasi maka hasilnya jumlah celah struktur jaringan komunikasi berjumlah 604 celah. Jumlah itu termasuk besar sehingga akun @PBDjarum sebagai ego mendapatkan keuntungan atas informasi yang disampaikannya. Selain itu, akunakun sebagai alter dalam jaringan komunikasi menjadi ketergantungan atas informasi yang disampaikan oleh akun@PBDjarum. Analisis kekuatan ikatan antarakun dilakukan untuk mengetahui kuat lemahnya ikatan antara akun @ PBDjarum sebagai ego dengan akun-akun lain sebagai alter. Setelah dilakukan analisis kekuatan ikatan antar akun, hasilnya nilai ikatan antar akun sebesar 1,997. Nilai tersebut menunjukkan ikatan yang lemah karena akun-akun sebagai alter belum mengenali satu dengan yang lainnya.

Analisis tingkat kelompok dalam jaringan komunikasi terpusat akun@PBDjarum dapat dijelaskan dengan mengetahui jumlah kelompok perantara dalam jaringan komunikasi terpusat. Jumlah kelompok perantara dalam jaringan komunikasi bisa menentukan seberapa penting posisi akun@PBDjarum sebagai ego kepada akun-akun lain sebagai alter sehingga akun
@PBDjarum mempunyai kontrol informasi kepada akun-akun lain. Gambar 1 menunjukkan 13 kelompok yang menjadi kelompok perantara dalam jaringan komunikasi. Selanjutnya akun @ PBDjarum mempunyai kontrol informasi tentang audisi PB Djarum 2019 sehingga memunculkan persamaaninformasi yang disampaikankepada 13 kelompok perantara dalam jaringan komunikasi.

Analisis tingkat struktur jaringan komunikasi terpusat akun@PBDjarum dengan cara mengetahui seberapa ukuran nilai kepadatan jaringan dan nilai ukuran jarak diameter jaringan. Ketentuan ukuran jarak diameter jaringan komunikasi adalah semakin dekat jarak diameter jaringan komunikasinya maka semakin kuat struktur jaringan komunikasinya. Begitu pula sebaliknya, semakin jauh jarak diameter jaringan komunikasimakasemakinlemah strukturjaringan komunikasinya. Ketentuan nilai kepadatan jaringan komunikasi berkisar dari angka 0 sampai angka 1. Nilai kepadatan jaringan komunikasi yang mendekati angka 1 maka struktur jaringan komunikasinya terbentuk sangat padat. Begitu pula sebaliknya jika nilai kepadatan jaringan komunikasi mendekati angka 0 maka struktur jaringan komunikasinya tidak padat. Setelah melakukan analisis struktur jaringan komunikasi terpusat akun@PBDjarum, hasilnya nilai jarak diameter jaringan komunikasi yaitu 2 ikatan dan nilai kepadatan jaringan komunikasi yaitu 0,003 . Nilai jarak diameter jaringan komunikasi tersebut memiliki arti bahwa struktur jaringan komunikasi terpusat akun@PBDjarum memiliki struktur jaringan komunikasi yang kuat. Selain itu, struktur jaringan komunikasi yang kuat disebabkan oleh akun-akun sebagai alter yang berkomunikasi langsung tidak lebih melewati 2 ikatan dari akun-akun. Nilai kepadatan jaringan komunikasi dapat dijelaskan bahwa struktur jaringan komunikasi terpusat akun@ PBDjarum tidak terlalu padat karena akunakun sebagai alter yang jarang berinteraksi secara langsung dalam jaringan komunikasi. 
Gambar 2 Jaringan komunikasi terpusat akun@lenteraanak_

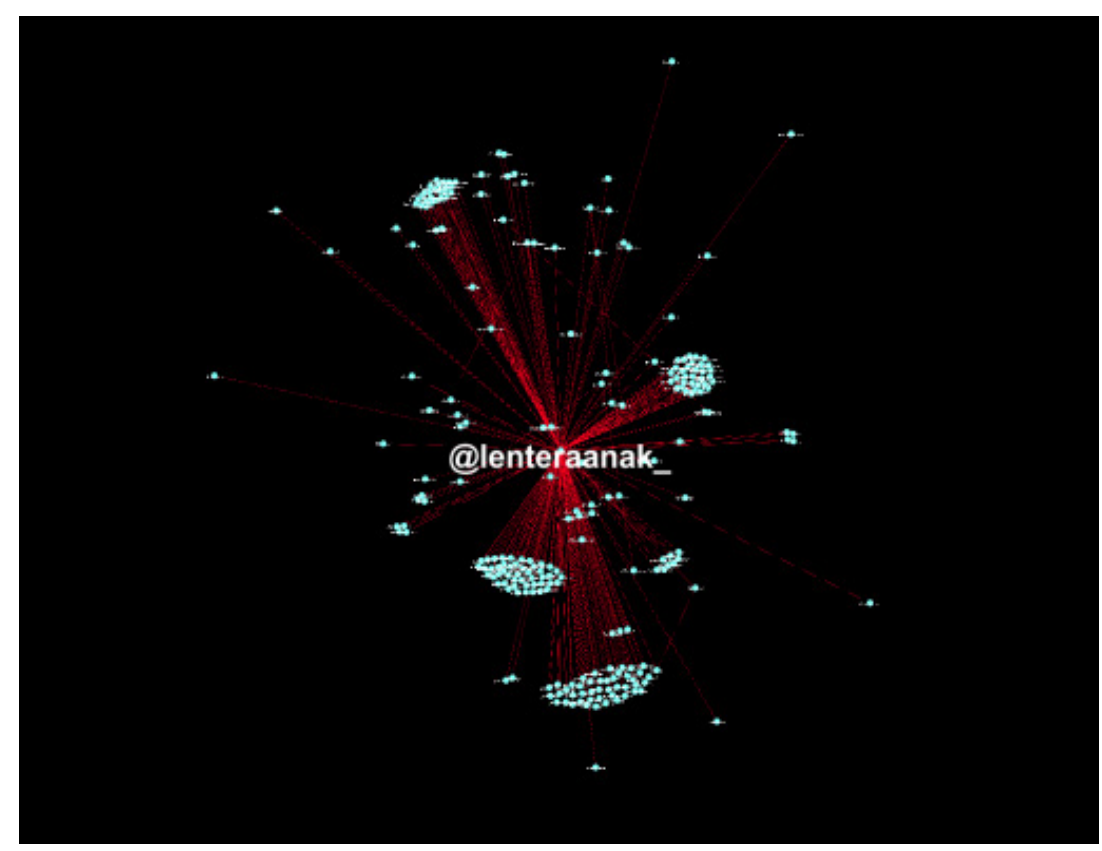

Sumber : Data diolah dari software Gephi (2019).

\section{Jaringan Komunikasi Terpusat akun (Ienteraanak}

Gambar 2 menunjukkan jaringan komunikasi terpusat pada akun @lenteraanak_. Jaringan komunikasi tersebut memiliki akun berjumlah 244 dengan 253 interaksi dan titiktitik berwarna biru muda sebagai tanda akun dan garis-garis berwarna merah sebagai interaksi.

Analisis tingkat akun Twitter pada jaringan komunikasi terpusatdiakun@lenteraanak_yaitu menganalisis ketertutupan jaringan komunikasi, celah struktur jaringan komunikasi dan ikatan antar akun-akun. Akun @lenteraanak_sebagai ego dan akun-akun lain sebagai alter. Analisis ketertutupan jaringan komunikasi dilakukan untuk mengetahui tinggi rendahnya keterikatan diantara akun-akun sebagai alter dalam jaringan komunikasi. Setelah melakukan analisis ketertutupan jaringan komunikasi maka hasilnya nilai indeks integrasi jaringan komunikasi atau nilai ketertutupan jaringan komunikasi pada jaringankomunikasiterpusatakun@lenteraanak_ sebesar 0,035. Nilai tersebut menandakan cukup rendahnya keterikatan antar akun sebagai alter dalam jaringan komunikasi. Penjelasan cukup rendahnya keterikatan akun-akun sebagai alter karena akun-akun tersebut belum saling mengenal satu dengan yang lainnya. Analisis celah struktur jaringan komunikasi bertujuan untuk mengetahui ruang kosong dalam jaringan komunikasi yang mana akun@lenteraanak_ sebagai ego menjadi suatu ketergantungan dari akun-akun lain sebagai alter. Berdasarkan analisis celah struktur jaringan komunikasi maka hasilnya jumlah celah struktur jaringan komunikasi sebanyak 239 celah. Jumlah tersebut termasuk besar sehingga akun@lenteraanak_ sebagai ego mendapatkan keuntungan atas informasi yang disampaikannya. Selain itu, akun alter dalam jaringan komunikasi menjadi agak ketergantungan atas informasi yang disampaikan oleh akun@lenteraanak_. Analisis kekuatan ikatan antar akun dilakukan untuk mengetahui kuat lemahnya ikatan antara akun @lenteraanak_ sebagai ego dengan akun-akun lain sebagai alter. Setelah peneliti melakukan analisis kekuatan ikatan antar akun maka hasilnya nilai ikatan antar akun sebesar 1,991. Nilai tersebut menunjukkan ikatan yang lemah karena akun-akun sebagai alter belum mengenali satu sama lainnya. 
Analisis tingkat kelompok-kelompok dalam jaringan komunikasi terpusat akun@ lenteraanak_yaitu dengan menghitung jumlah kelompok perantara dalam jaringan komunikasi terpusat. Jumlah kelompok perantara dalam jaringan komunikasi bisa menentukan seberapa penting posisi akun@lenteraanak_sebagai ego kepada akun-akun lain sebagai alter sehingga akun @lenteraanak_mempunyai kontrol informasi kepada akun-akun lain. Gambar 2 menunjukkan ada 16 kelompok yang menjadi kelompok perantara dalam jaringan komunikasi. Akun @ lenteraanak_ mempunyai kontrol informasi tentang laporan dugaan eksploitasi anak pada audisi PB Djarum 2019 sehingga memunculkan persamaaninformasiyang disampaikankepada 13 kelompok perantara dalam jaringan komunikasi.

Analisis tingkat struktur jaringan komunikasi terpusat akun@lenteraanak_yaitu dengan cara mengetahui ukuran kepadatan jaringan komunikasi dan ukuran jarak diameter jaringan komunikasi. Ketentuan ukuran jarak diameter jaringan komunikasi adalah semakin dekat jarak diameter jaringan komunikasinya maka semakin kuat struktur jaringan komunikasinya. Begitu pula sebaliknya, semakin jauh jarak diameter jaringan komunikasinya maka semakin lemah struktur jaringan komunikasinya. Ketentuan nilai kepadatan jaringan komunikasi berkisar dari angka 0 sampai angka 1. Nilai kepadatan jaringan komunikasi yang semakin mendekati angka 1 maka struktur jaringan komunikasinya terbentuk sangat padat. Sebaliknya, jika nilai kepadatan jaringan komunikasi mendekati angka 0 maka struktur jaringan komunikasinya tidak padat. Setelah peneliti melakukan analisis struktur jaringan komunikasi terpusat akun @ lenteraanak_maka hasilnya nilai jarak diameter jaringan komunikasi yaitu 2 ikatan dan nilai kepadatan jaringan komunikasi yaitu 0,009.
Nilai jarak diameter jaringan komunikasi tersebut berarti bahwa jaringan komunikasi terpusat akun@lenteraanak_memiliki struktur yang kuat. Struktur jaringan komunikasi yang kuat disebabkan oleh adanya akun-akun sebagai alter yang berkomunikasi langsung tidak lebih melewati 2 ikatan dari akun-akun. Nilai kepadatan jaringan komunikasi tersebut menjelaskan bahwa struktur jaringan komunikasi terpusat akun@lenteraanak_tidak terlalu padat karena akun-akun sebagai alter yang jarang berinteraksi secara langsung dalam jaringan komunikasi.

Jaringan komunikasi memiliki konsep penelitian yaitu konsep aktor dan konsep relasi antar aktor. Jika dikaitkan dengan hasil penelitian maka telah diketahui ada perbedaan hasil aktor dan hasil relasi antar aktor pada jaringan komunikasi terpusat akun@PBDjarum dan@lenteraanak_.Perbedaan hasil penelitian menjelaskan jaringan komunikasi terpusat akun @PBDjarum dan@lenteraanak_memiliki karakteristik jaringan tersendiri. Hasil penelitian menjadi kebaruan jika dibandingkan dengan hasil penelitian yang relevan sebelumnya (Lipschultz, 2017; Nandiwardhana et al., 2019; Ramadhani et al., 2018; Sugiarta et al., 2018; Tomasoa et al., 2019). Hasil penelitian sebelumnya hanya membahas hasil sentralitas aktor yang menjadi tokoh kunci penyebaran informasi dalam jaringan komunikasi. Berbeda dengan hasil penelitian sebelumnya, penelitian ini tidak hanya membahas hasil aktor saja namun ada pembahasan mengenai perbedaan suatu karakteristik jaringan komunikasi. Perbedaan tersebut dapat diketahui dengan melihat penjelasan analisis kelompok dan struktur jaringan komunikasi. Substansi penelitian ini berupa penemuan metode baru analisis jaringan komunikasi tentang sebuah isu yang bisa membedakan karakteristik jaringan komunikasi terpusat pada setiap akun di Twitter. 


\section{Simpulan}

Isu polemik audisi PB Djarum tahun 2019 memunculkan jaringan komunikasi terpusat oleh akun@PBDjarumdan@lenteraanak_di Twitter. Jaringan komunikasi terpusat oleh akun@ PBDjarum di Twitter mendapatkan lebih banyak interaksi dengan akun-akun lain di Twitter. Hal tersebut terjadi karena akun@PBDjarum telah melakukan interaksi dengan jumlah akun yang lebih banyak daripada akun@lenteraanak_akan tetapi jaringan komunikasi terpusat oleh akun @ lenteraanak_di Twitter mendapatkan penyebaran informasi yang lebih cepat dengan akun-akun lain di Twitter. Hal tersebut dapat ditunjukkan pada jumlah kelompok perantara oleh akun @ lenteraanak_ yang lebih banyak dari pada akun @)PBDjarum. Struktur jaringan komunikasi terpusat akun@PBDjarum dan@lenteraanak_ memiliki jarak diameter jaringan yang dekat serta kepadatan jaringan yang tidak padat. Hal tersebut menyimpulkan bahwa struktur jaringan komunikasi kedua akun tersebut kuat interaksinya kepada akun-akun lain di Twitter tetapi pada waktu yang tidak selalu bersamaan interaksinya. Jaringan komunikasi terpusat tentang isu polemik audisi PB Djarum 2019 di Twitter dapat disimpulkan memunculkan banyak interaksi sehingga persebaran informasi atas isu tersebut dapat diterima begitu cepat dan luas oleh masyarakat Indonesia. Substansi penelitian ini berupa temuan baru mengenai analisis jaringan komunikasi Twitter, khususnya karakteristik jar ingan komunikasi terpusat akun@PBDjarum berbeda dengan karakteristik jaringan komunikasi terpusat akun @lenteraanak_.

\section{Daftar Pustaka}

Carey, J. W. (2008). Communication as culture: Essays on media and society: Revised edition. In Communication as Culture: Essays on Media and Society: Revised Edition. https://doi.org/10.4324/9780203928912
Carr, C. T., \& Hayes, R. A. (2015). Social Media: Defining, Developing, and Divining. Atlantic Journal of Communication, 23(1), 46-65. https:// doi.org/10.1080/15456870.2015.972282

Cherven, K. (2013). Network graph analysis and visualization with Gephi: visualize and analyze your data swiftly using dynamic network graphs built with Gephi. Birmingham: Packt Publishing. Cherven, K. (2015). Mastering Gephi Network Visualization. Retrieved from http://www.amazon.com/MasteringGephi-Network-Visualization-Cherven/ $\mathrm{dp} / 1783987340 /$ ref $=$ sr_1_1 $\mathrm{ie}=\mathrm{UTF} 8 \& \mathrm{q}$ $\mathrm{id}=1430851698 \& \mathrm{sr}=8-1 \& \mathrm{keywords}=\mathrm{M}$ astering + Gephi + Network + Visualization

Coleman, J. S. (1988). Social capital in the creation of human capital. Knowledge and Social Capital, 94, 17-42. https://doi.org/10.1086/228943 Eriyanto. (2014). Analisis Jaringan Komunikasi. Jakarta: Prenada Media Group. Fernandez,R.M.,\&Gould,R.V.(1994).ADilemma of State Power: Brokerage and Influence in the National Health Policy Domain. American Journal of Sociology, 99(6), 1455-1491. https://doi.org/10.1086/230451

Firmansyah, M. A. (2018). Kontestasi Pesan Politik dalam Kampanye Pilpres 2014 di Twitter: Dari Kultwit Hingga Twitwar. Jurnal Ilmu Komunikasi, 16(1), 42-53.

Granovetter, M. S. (1973). The strength of weak ties In Social networks. American Journal of Sociology, 78(6), 1360-1380. https:// doi.org/10.1017/S0269889712000130

Holmes, D. (2005). Communication Theory: Media, technology and society. London: SAGE Publications.

Jk, S. (2017). Jaringan Komunikasi tentang Inovasi Obyek dan Strategi Kelompok Pengemis di Kampung Padangan di Kota Solo. 15, 120-133. 
Kadushin, C. (2012). Understanding Social Networks: Theories, Concepts and Findings. New York: Oxford University Press. Kaplan, A. M., \& Haenlein, M. (2010). Users of the world, unite! The challenges and opportunities of Social Media. Business Horizons, 53(1), 59-68. https://doi. org/10.1016/j.bushor.2009.09.003

Lazega, E., \& Burt, R. S. (1995). Structural Holes: The Social Structure of Competition. In Revue Française de Sociologie (Vol. 36). https://doi.org/10.2307/3322456

Lipschultz, J. H. (2017). Organizations, HR, CSR, and Their Social Networks: "Sustainability" on Twitter. Corporate Social Responsibility, Sustainability, and Ethical Public Relations, 35-52. https://doi. org/10.1108/978-1-78714-585-620181002 Murthy, D. (2013). Twitter: Digital Media and Society Series. Cambridge: Polity Press. Nandiwardhana, B. G., Pratama, B. I., \& Tamitiadini, D. (2019). Study of Communication Network Travel-Related eWOM on Instagram Social Media. Journal Pekommas, 4(1), 97. https:// doi.org/10.30818/jpkm.2019.2040110

Ramadhani, D. P., Alamsyah, A., \& Wicaksono, M. B. (2018). Eksplorasi Pemimpin Opini Untuk Alternatif Pendukung Pemasaran Pt . Net Mediatama Indonesia Menggunakan Metode Analisis Jejaring Sosial Dengan Kata Kunci “@ Netmediatama” Di Twitter. Jurnal Wacana Ekonomi, 17, 13-24.
Reilly, T. O., \& Milstein, S. (2009). The Twitter Book. California: O'Reilly Media. Russell, M., \& Klassen, M. (2019). Mining the Social Web: Data Mining Facebook, Twitter, LinkedIn, Instagram, GitHub, and More (Third). California: O'Reilly Media. Sugiarta, A. I., Syamsuar, D., \& Negara, E. S. (2018). Analisis Sentralitas Aktor pada Struktur Jaringan Politik dengan Menggunakan Metode Social Network Analysis ( SNA ): Studi Kasus Group Facebook Lembaga Survei Sosial Media. Semnastik, 1-7. Palembang. Tomasoa, L., Iriani, A., \& Sembiring, I. (2019). Ekstraksi Knowledge tentang Penyebaran \#Ratnamiliksiapa pada Jejaring Sosial (Twitter) menggunakan Social Network Analysis (SNA). Jurnal Teknologi Informasi Dan Ilmu Komputer, 6(6), 677-686. https://doi.org/10.25126/jtiik.2019661710 Wardyaningrum, D. (2010). Pola Komunikasi Keluarga dalam Menentukan Konsumsi Nutrisi bagi Anggota Keluarga. Ilmu Komunikasi, Vol 8, No, 289-298. Wasserman, S., \& Faust, K. (1994). Social NetworkAnalysis: Methods and Applications. Cambridge: Cambridge University Press. We Are Social, \& Hootsuite. (2019). Digital DATA OVERVEW 2019: Indonesia. In Global Digital Insights. Retrieved from https://datareportal. com/reports/digital-2020-indonesia 